\title{
Resenha
}

Review

\section{Eutanásia e Seguro de Vida: análise do direito à percepção da indenização}

Euthanasia and Life Insurance: analysis of the entitlement to be indemnified

Luciana Gonzaga de Oliveira ${ }^{1}$

O livro em destaque é a primeira obra do autor Igor de Lucena, jurista, professor universitário, advogado e escritor. Dividido em três capítulos, o trabalho se propõe analisar o eventual direito à indenização no contrato de seguro de vida em caso de prática de eutanásia e a viabilidade de reconhecimento como direito, para a natureza jurídica.

O primeiro capítulo, apresenta conceitos essenciais sobre vida, morte e eutanásia. É fato que a morte é a única certeza pós nascimento que temos. O ciclo da vida é formado por nascer, crescer, se reproduzir e morrer. A grande questão por outro lado, é qual o momento da chegada. Em fase de discussão humana acerca da morte, expressões como eutanásia, e suas classificações, que existem ao menos seis " espécies", de eutanásia: eutanásia direta/indireta, consensual/não- consensual, passiva autoeutanásia (suicídio assistido), além de duas figuras próximas que são a ortotanásia e a distanásia. A multiplicidade de espécies é a grande dificuldade no estudo da eutanásia no Brasil, que no ordenamento jurídico, hoje não existe nada que regulamente ou conceitue o que vem a ser a eutanásia. Uma norma administrativa é a única existente no País, ainda que de forma não explícita, o Código de Ética Médica (CEM/2010), nos termos no art. 41. Proíbe a eutanásia e permite a ortotanásia.

Pouco se discute sobre existência de deveres fundamentais. Há uma pequena discussão no âmbito tributário, porém a doutrina é praticamente incipiente no tocante aos demais ramos do direito, sobretudo o cível. A autonomia do paciente enquanto direito fundamental, deriva da liberdade que é, simultaneamente, "valor supremo do

\footnotetext{
${ }^{1}$ Graduada em Saúde Coletiva pela Universidade de Brasília (UnB). E-mail: Lucianagoliveira7@gmail.com
} 
Estado Democrático de Direito, objetivo fundamental da República e também um direito fundamental". Na fase atual do Direito Médico, a autonomia do paciente representa a quebra do paternalismo profissional e a aceitação de que o paciente não pode ser encarado apenas como objeto de atuação médica, mas nomeadamente, enquanto sujeito de direito.

O segundo capítulo, o contrato de seguro de vida, o autor coloca um breve resumo acerca sobre as formas de contratos, seguro e a seguradora. Partindo da referida questão do consumidor e seu poder precaucionais de ocorrência de uma hipótese de risco, a seguradora, no entanto assume o ônus sofrido. Com relação ao suicídio como causa excludente do dever de indenizar, o Código Civil em seu artigo 798, traz uma cláusula excludente do dever de indenizar no caso do contrato de vida se o segurado se suicidar nos dois primeiros anos do contrato. Mas a interpretação a priori, deve ser restritiva, de sorte que as normas de direito econômico, por serem de via de regra, normas proibitivas, não podem ser interpretadas de forma extensiva. A excludente do dever de indenizar em casos de suicídio decorre em suma, da função social do contrato e da boa-fé objetiva. Presuma se que ninguém seria frio o suficiente para firmar um contrato de seguro e aguardar 02 anos para só então cometer o suicídio. Deste modo, tem- se que o contrato tem a função social e que, superado o prazo de 02 anos, tem que ser garantida a sua eficácia e aplicabilidade. Representa uma conduta contraditória o suicídio cometido em vigência de contrato de seguro de vida e a busca da indenização, uma vez que o sinistro é dotado de risco de adversidade, todavia uma vez realizado o suicídio, tem - se verdadeiro aspecto de vontade como força motriz do ato jurídico, este considerado enquanto atuação humana dependente de vontade.

O terceiro e último capítulo, retrata a Eutanásia e o Seguro de Vida, no contexto jurídico, as dificuldades e problemas enfrentados, tanto na forma do legislativo, as decisões estritamente sociais que prejudicam o mercado, as decisões judiciais que são afetadas pelo julgador e afetam diretamente o mercado de seguro. A inserção da figura da eutanásia no ordenamento jurídico brasileiro através do código penal traz o seguinte problema: como regular a eutanásia, ante a 
ausência de dispositivo legal, no que refere aos demais ramos do direito? $\mathrm{O}$ autor responde então esta questão, sobre a eficiência do judiciário que deve ser mensurada a partir da garantia de acesso, celebridade das decisões. O Brasil possui uma jurisprudência difusa e oscilante, de modo que posicionamentos, outrora sólidos, são destruídos rapidamente. Logo, litigiar e, sobretudo, uma jurisprudência que era desfavorável, torna-se favorável.

Enquanto a crise no legislativo gera uma produção de leis ruins ou sem reconhecer o direito como um sistema uno, em que os seus ramos estão em comunicação constante, a norma não alcançará sua finalidade máxima, pois estará limitada pelo próprio poder responsável pela sua concepção. O Judiciário deve promover uma análise de custo benefício dos custos sociais, sob o prisma individual, mas que comprometem todo o mercado. O Estado - Juiz deve avançar e intervir nos casos necessários para recompor a equidade e o equilíbrio contratual.

Conclua-se que nesse sentido as normas do Direito econômico inseridas no Código Civil visam proteger o mercado e os próprios consumidores. Entender que a eutanásia não pode ser interpretada como cláusula excludente do dever de indenizar é garantir um planejamento da morte, uma vez que os indivíduos racionais passarão não mais se suicidar e sim serem "vítimas" do ato de eutanásia. A interpretação mais adequada e racional é que a eutanásia, enquanto não sobrevenha lei específica reguladora, seja equiparada, nos contratos de seguro de vida, ao suicídio, de sorte que tenhamos um mesmo resultado. Desta forma, a morte pode ser analisada sob o prisma da eutanásia consensual, não consensual, indireta, ortotanásia e distanásia, esta que, enquanto medida antiética e desumana, não pode ser exigida pela companhia seguradora, de modo que a exigência de prática distanásica para recebimento da indenização representaria a inversão dos valores e a supremacia do interesse econômico sobre a dignidade da pessoa humana, enquanto prolongamento artificial da vida, deve ser coibida e não exigida pelas seguradoras

É proposta que o tratamento dispensado a eutanásia direta consensual seja o mesmo dado a eutanásia direta consensual seja o mesmo dado ao suicídio, ao passo que semelhantes como eutanásia não consensual e eutanásia indireta devem ser tratados como homicídio e o sinistro propriamente dito, pois na primeira não há 
participação do paciente e na segunda, a vontade é direcionada para minorar a dor e não abreviar a vida, de ambas devem ser indenizadas. A ortotanásia, como morte no tempo correto, deve ser interpretada como fundamento para pagamento.

O Livro traz diversas críticas relevantes e atual, tema este polêmico, seja no contexto religioso e social, destaca se a questão contratual de seguro de vida, nos casos específicos de eutanásia, que enquanto exercício de autonomia privada, representa o reconhecimento de que a vida deve se pautar por uma ótica pessoal e subjetiva.

\section{Referência}

Mascarenhas IL. Eutanásia e Seguro de vida: Análise do Direito à Percepção da Indenização. Rio de Janeiro (RJ). Editora Lumen Juris. 2017 